\title{
PENGETAHUAN DAN SIKAP PASANGAN USIA SUBUR DALAM PENCEGAHAN HIV/AIDS
}

\author{
Rochany Septiyaningsih ${ }^{1}$, Dhiah Dwi Kusumawati ${ }^{2}$, Septiana Indratmoko ${ }^{3}$ \\ Universitas Al-Irsyad Cilacap ${ }^{123}$ \\ e-mail: ${ }^{1}$ rochany.septiyaningsih87@gmail.com, ${ }^{2}$ dhiahdwi@gmail.com, ${ }^{3}$ indratmoko86@gmail.com
}

\begin{abstract}
Human Immunodeficiency Virus (HIV) and Acquired Immunodeficiency Syndrome (AIDS) are still health problems faced by both developed and developing countries. One of the main factors that become obstacles is the stigma and discrimination against HIV sufferers in Indonesia which is still high. The age group most infected with HIV/AIDS in Indonesia is included in the population of couples of childbearing age. EFA is a couple (male and female) who are mature enough in all respects, especially their reproductive organs that are already functioning properly. At this time EFA must be able to maintain and utilize its reproduction properly. The purpose of this study is to describe the knowledge and attitudes of couples of childbearing age in preventing HIVIAIDS in the Work Area of the South Cilacap Health Center II. This study used a descriptive research design with a cross sectional approach. Samples were taken by random sampling technique, amounting to 30 respondents with univariate analysis. The results of this study were sufficient knowledge of respondents about HIVIAIDS 16 respondents (53.3\%), both 12 respondents (40\%) and less than 2 respondents (6.7\%) as well as positive attitudes 24 respondents (80\%) and negative attitudes 6 respondents $(20 \%)$.
\end{abstract}

Keywords: HIV, PUS, attitude, knowledge

\begin{abstract}
ABSTRAK
Human Immunodeficiency Virus (HIV) dan Acquired Immunodeficiency Syndrome (AIDS) hingga saat ini masih menjadi masalah kesehatan yang dihadapi baik oleh negara maju maupun negara berkembang. Salah satu faktor utama yang menjadi kendala adalah stigma dan diskriminasi terhadap penderita HIV di Indonesia yang masih tinggi. Kelompok umur yang terbanyak terinfeksi HIV/AIDS di Indonesia termasuk dalam populasi pasangan usia subur. PUS adalah pasangan (laki-laki dan perempuan) yang sudah cukup matang dalam segala hal terlebih organ reproduksinya yang sudah berfungsi dengan baik. Pada masa ini PUS harus dapat menjaga dan memanfaatkan reproduksinya dengan baik. Tujuan penelitian ini menggambarkan pengetahuan dan sikap Pasangan Usia Subur dalam pencegahan HIV/AIDS di Wilayah Kerja Puskesmas Cilacap Selatan II. Penelitian ini menggunakan desain penelitian deskriptif dengan pendekatan cross sectional. Sampel diambil dengan teknik random sampling yang berjumlah 30 responden dengan analisis univariat. Hasil penelitian ini pengetahuan responden tentang HIV/AIDS cukup 16 responden (53,3\%), baik 12 responden (40\%) dan kurang 2 responden $(6,7 \%)$ serta sikap positif 24 responden (80\%) dan sikap negatif 6 responden $(20 \%)$.
\end{abstract}

Kata kunci: HIV, PUS, sikap, pengetahuan

\section{PENDAHULUAN}

Human Immunodeficiency Virus (HIV) dan Acquired Immunodeficiency Syndrome (AIDS) hingga saat ini masih menjadi masalah kesehatan yang dihadapi baik oleh negara maju maupun negara berkembang. Penyebab HIV adalah human papilloma virus yang masuk ke dalam tubuh manusia dan menyerang sel darah putih yang bertugas sebagai pertahanan terhadap infeksi. Hal tersebut menyebabkan penurunan sistem kekebalan tubuh sehingga tubuh akan mudah terserang berbagai penyakit ${ }^{1}$. Kumpulan tanda dan gejala penyakit yang diakibatkan menurunnya sistem kekebalan tubuh yang diperoleh disebut AIDS $^{2}$.
Berdasarkan data WHO pada akhir tahun 2017 menyatakan bahwa 36,9 juta orang terkena HIV/AIDS, 940.000 mengalami kematian karena HIV dan sekitar 1,8 juta orang terinfeksi baru HIV (WHO, 2018). Di Indonesia, insiden HIV/AIDS tahun 2017 ditemukan sebesar 48.300 HIV positif dan 9.280 kasus AIDS $^{3}$. Insiden tersebut menempatkan Indonesia di urutan teringgi ketiga jumlah ODHA dan infeksi baru di wilayah Asia Pasifik setelah India dan China (WHO, 2018). Data per Juni 2019 jumlah HIV/AIDS di Indonesia mencapai 349.883 kasus, terbanyak pada kelompok umur 25-49 tahun (71,1\%), kemudian kelompok umur 20-24 tahun $(14,4 \%)$ dan kelompok umur $\geq 50$ tahun $(9 \%)^{4}$. 
Penurunan epidemi HIV di Indonesia dapat dikatakan masih jauh dari target. Walaupun beberapa program pengendalian HIV/AIDS telah digalakkan, namun tidak dapat dipungkiri keberadaan beberapa kendala berikut ini mempengaruhi keberhasilan program tersebut. Salah satu faktor utama yang menjadi kendala adalah stigma dan diskriminasi terhadap penderita HIV di Indonesia yang masih tinggi. UNAIDS melaporkan bahwa lebih dari setengah penduduk $(62,8 \%)$ menyatakan tidak akan membeli sayuran dari penjual sayur yang menderita $\mathrm{HIV}^{5}$. Hal ini menunjukkan bahwa pencapaian Indonesia untuk zero discrimination masih jauh.

Keberadaan stigma dan diskriminasi membuat ODHA mengalami penderitaan ganda. Stigma dan diskriminasi ini juga menjadi faktor yang menghambat penjangkauan, diagnosis, dan penerimaan layanan kesehatan yang berkualitas bagi ODHA, khususnya pada populasi kunci. Penelitian terkait stigma di Indonesia menemukan beberapa bentuk stigma yang diterima ODHA yaitu berupa penolakan, harga diri rendah/persepsi diri yang negatif, pelecehan verbal, isolasi sosial, dan ketakutan. Bahkan keberadaan stigma ini membuat $45 \%$ dari mereka merasa tidak layak untuk hidup dan $64 \%$ merasa tidak berharga ${ }^{6,7}$.

Stigma dan diskriminasi yang mereka terima ini disebabkan karena penderita HIV yang sering dikaitkan dengan isu narkoba, seks bebas, dan homoseksual. Faktanya diketahui bahwa penularan HIV terbanyak di Indonesia disebabkan karena hubungan heteroseksual dan penderita terbanyaknya adalah ibu rumah tangga ${ }^{8}$. Kondisi ini menepis bahwa penderita HIV yang selalu dikaitkan dengan perilaku menyimpang. Sementara itu jika dikaitkan dengan program yang ada, kampanye pencegahan ditujukan hanya pada kelompok yang dianggap rentan, padahal semua orang dengan orientasi seksual apapun rentan terhadap HIV/AIDS. Peningkatan layanan informasi, edukasi, dan konseling HIV/AIDS pada seluruh lapisan masyarakat merupakan salah satu cara yang terbukti efektif dalam penurunan tingkat stigma ${ }^{9}$. Selain itu untuk mendukung kejiwaan ODHA, juga perlu dipertimbangkan keberadaan akses kepada layanan kesehatan mental yang juga perlu menjadi prioritas pada klinik yang menyediakan terapi $\mathrm{ARV}^{6}$.

Provinsi Jawa Tengah menempati posisi kelima untuk kasus HIV/AIDS di Indonesia.
Berdasarkan data dari Dinas Kesehatan Jawa Tengah bahwa epidemi HIV/AIDS di Jawa Tengah sejak 1993 sampai September 2019 sebanyak 30.465 penderita, dengan rincian 17.559 kasus HIV, 12.906 kasus AIDS dan sebanyak 1.915 orang di antaranya sudah meninggal dunia. Kelompok umur yang terbanyak terinfeksi HIV/AIDS di Indonesia termasuk dalam populasi pasangan usia subur. Pasangan usia subur adalah pasangan (laki-laki dan perempuan) yang sudah cukup matang dalam segala hal terlebih organ reproduksinya yang sudah berfungsi dengan baik. Pada masa ini PUS harus dapat menjaga dan memanfaatkan reproduksinya dengan baik ${ }^{10}$.

Sistem reproduksi PUS dapat berfungsi dengan baik jika tidak terdapat masalah reproduksi seperti HIV/AIDS. Berdasarkan Peraturan Menteri Kesehatan Republik Indonesia nomor 21 tahun 2013 pasal 9 tentang kegiatan penanggulangan HIV dan AIDS antara lain : promosi kesehatan, pencegahan penularan HIV, pemeriksaan diagnosis HIV, penggobatan, perawatan, dukungan, dan rehabilitas. Konseling yang berkualitas serta penggunaan alat kontrasepsi yang efektif dapat membantu perempuan terhadap penularan HIV/AIDS. Kegiatan penanggulangan HIV/AIDS diharapkan dapat meningkatkan pengetahuan dan perilaku PUS tentang HIV/AIDS sehingga menurunkan risiko terkena HIV/AIDS.

Pengetahuan merupakan salah satu faktor terbentuknya perilaku kesehatan. Apabila PUS mengetahui dan memahami tentang HIV/AIDS dan pencegahan HIV/AIDS maka akan mempunyai sikap dan perilaku kesehatan sehingga diharapkan dapat terhindar dari berbagai akibat atau risiko terjadinya HIV/AIDS. Pengetahuan seseorang akan berpengaruh terhadap sikap yang dilakukan khususnya pada kasus Penyakit Menular Seksual ${ }^{11}$. Penelitian lain juga menunjukkan bahwa terdapat hubungan yang signifikan antara pengetahuan tentang HIV/AIDS dengan sikap dalam pencegahan HIV/AIDS ${ }^{12}$.

Berdasarkan data Dinas Kesehatan Kabupaten Cilacap, kejadian HIV/AIDS sampai dengan bulan September 2020 mencapai 1.755 kasus $^{13}$. Kecamatan Cilacap Selatan menjadi wilayah yang tertinggi angka kejadian HIV yaitu sebanyak 138 kasus pada tahun 2019. Puskesmas Cilacap Selatan II merupakan salah satu puskesmas di Kecamatan Cilacap Selatan yang berada di pesisir laut, wilayahnya cukup banyak 
terdapat rumah kontrakan dan cukup banyak yang berprofesi sebagai nelayan dan pemandu lagu. Berdasarkan hal tersebut peneliti tertarik untuk melakukan penelitian dengan judul "Pengetahuan Dan Sikap Pasangan Usia Subur Dalam Pencegahan HIV/AIDS di Wilayah Kerja Puskesmas Cilacap Selatan II".

Tujuan penelitian ini menggambarkan pengetahuan dan sikap Pasangan Usia Subur dalam pencegahan HIV/AIDS di Wilayah Kerja Puskesmas Cilacap Selatan II.

\section{METODE}

Penelitian ini menggunakan desain penelitian deskriptif dengan pendekatan cross sectional. Sampel diambil dengan teknik random sampling yang berjumlah 30 responden dengan analisis univariat. Penelitian dilakukan di Wilayah Kerja Puskesmas Cilacap Selatan II. Subyek penelitian adalah PUS yang telah menandatangani informed consent. Instrumen penelitian menggunakan kuesioner.

\section{HASIL}

1. Pengetahuan PUS Tentang HIV/AIDS Di Wilayah Kerja Puskesmas Cilacap Selatan II

Tabel 1. Distribusi Frekuensi Tingkat Pengetahuan PUS Tentang HIV/AIDS Di Wilayah Kerja Puskesmas Cilacap Selatan II

\begin{tabular}{cccc}
\hline No & $\begin{array}{c}\text { Kategori } \\
\text { Pengetahuan }\end{array}$ & $\begin{array}{c}\text { Frekuensi } \\
\text { (f) }\end{array}$ & $\begin{array}{c}\text { Persentase } \\
(\boldsymbol{\%})\end{array}$ \\
\hline $\mathbf{1}$ & Baik & 12 & 40 \\
\hline $\mathbf{2}$ & Cukup & 16 & 53,3 \\
\hline $\mathbf{3}$ & Kurang & 2 & 6,7 \\
\hline & Jumlah & 30 & 100 \\
\hline
\end{tabular}

Sumber : Data Primer, 2021

Berdasarkan tabel di atas sebagian besar PUS memiliki pengetahuan cukup sebesar 53,3\%, pengetahuan baik sebesar $40 \%$ dan pengetahuan kurang sebesar $6,7 \%$.

\section{Sikap PUS Tentang HIV/AIDS Di Wilayah} Kerja Puskesmas Cilacap Selatan II

Tabel 2. Distribusi Frekuensi Sikap PUS Tentang HIV/AIDS Di Wilayah Kerja Puskesmas Cilacap Selatan II

\section{No Kategori Frekuensi Persentase}

\begin{tabular}{cccc}
\hline & Sikap & (f) & $(\boldsymbol{\%})$ \\
\hline $\mathbf{1}$ & Positif & 24 & 80 \\
\hline $\mathbf{2}$ & Negatif & 6 & 20 \\
\hline & Jumlah & 30 & 100 \\
\hline
\end{tabular}

Sumber: Data Primer, 2021

Berdasarkan tabel di atas sebagian besar PUS memiliki sikap positif sebesar $80 \%$ dan sikap negatif sebesar $20 \%$.

\section{PEMBAHASAN}

\section{Pengetahuan PUS Tentang HIV/AIDS Di Wilayah Kerja Puskesmas Cilacap Selatan II}

Berdasarkan hasil penelitian ini sebagian besar pengetahuan responden tentang HIV/AIDS adalah cukup yaitu sebanyak 16 responden $(53,3 \%)$, baik sebanyak 12 responden (40\%) dan kurang sebanyak 2 responden $(6,7 \%)$. Hasil penelitian ini sesuai dengan teori bahwa pengetahuan individu dapat berbeda beda karena pengetahuan dipengaruhi oleh faktor internal dan faktor ekternal. Faktor internal meliputi umur, pendidikan dan pekerjaan. Sedangkan faktor ekternal meliputi lingkungan dan sosial budaya. Hasil penelitian ini juga sejalan dengan penelitian yang dilakukan oleh Sri Wahyuni ${ }^{16}$. (2016) dengan hasil sebagian besar PUS memiliki pengetahuan yang cukup sebanyak 174 responden $(70,73 \%)$.

Hasil penelitian menunjukkan adanya variasi pengetahuan individu, hal ini dapat disebabkan karena individu mendapatkan pengetahuan tergantung dari kemampuan panca indera seseorang, sehingga semakin baik pula kemampuan seseorang untuk memperoleh informasi. Individu yang memperoleh kemampuan indera penglihatan untuk membaca, maka individu tersebut memiliki kesempatan yang lebih baik untuk mendapatkan informasi melalui buku, atau media cetak lainnya. Hal ini sesuai dengan teori yang mengungkapkan bahwa pengetahuan merupakan hasil dari tahu, dan ini terjadi setelah seseorang melakukan penginderaan terhadap suatu obyek tertentu. Penginderaan melalui panca indera manusia yaitu indera penglihatan, pendengaran, penciuman, rasa dan raba.

Menurut asumsi peneliti, bahwa pencegahan penularan HIV-AIDS merupakan tanggung jawab masing-masing individu, yang umumnya sangat dipengaruhi oleh 
faktor pengetahuan. Mereka yang memiliki tingkat pengetahuan HIV-AIDS tinggi, sikap dan perilaku pencegahan HIV-AIDS pun semakin baik.

2. Sikap PUS Tentang HIV/AIDS Di Wilayah Kerja Puskesmas Cilacap Selatan II

Berdasarkan hasil penelitian ini didapatkan sikap responden terhadap yaitu sikap positif sebanyak 24 responden $(80 \%)$ dan sikap negatif sebanyak 6 responden $(20 \%)$. Penelitian ini berbeda dengan yang dilakukan oleh Susianti ${ }^{17}$. (2014) yang menyatakan bahwa sebagian besar $(74,25 \%)$ WUS memiliki sikap negatif tentang HIV/AIDS. Sikap responden berbeda beda, hal ini sesuai dengan teori bahwa sikap seseorang dapat berbeda beda disebabkan ada beberapa faktor yang mempengaruhi sikap yaitu pengalaman pribadi, kebudayaan, pengaruh orang lain yang dianggap penting, media massa, institusi pendidikan dan faktor emosional.

Menurut Mubarak (2013), bahwa sikap adalah perasaan, pikiran dan kecenderungan seseorang yang kurang lebih bersifat permanen mengenai aspek-aspek tertentu dalam lingkungannya ${ }^{18}$. Sikap merupakan kecondongan evaluatif terhadap suatu stimulus atas objek yang berdampak pada bagaimana seseorang berhadapan dengan objek tersebut. Ini berarti sikap menunjukkan kesetujuan atau ketidaksetujuan, suka atau tidak suka seseorang terhadap sesuatu. Dalam penelitian ini, rasa setuju terhadap hal-hal yang positif mengenai pencegahan HIV-AIDS inilah yang membentuk sikap mereka menjadi positif. Hal ini didukung oleh tingkat pengetahuan tentang HIV-AIDS yang cukup sehingga membentuk sikap yang positif tentang HIV-AIDS tersebut. Menurut jurnal penelitian Shaluhiyah, dkk., (2015), pengetahuan tentang HIV-AIDS sangat memengaruhi sikap seseorang terhadap penderita HIV-AIDS ${ }^{19}$.

\section{KESIMPULAN}

1. Berdasarkan hasil penelitian ini sebagian besar pengetahuan responden tentang HIV/AIDS adalah cukup yaitu sebanyak 16 responden (53,3\%), baik sebanyak 12 responden $(40 \%)$ dan kurang sebanyak 2 responden $(6,7 \%)$.
2. Berdasarkan hasil penelitian ini didapatkan sikap responden terhadap yaitu sikap positif sebanyak 24 responden (80\%) dan sikap negatif sebanyak 6 responden $(20 \%)$.

\section{DAFTAR PUSTAKA}

1. Kumalasari I\& IA. Kesehatan Reproduksi Untuk Mahasiswa Kebidanan Dan Keperawatan. Salemba Medika; 2014.

2. Kusmiran E. Kesehatan Remaja Dan Wanita. Salemba Medika; 2012.

3. Kemenkes RI. Hari AIDS Sedunia, Momen STOP Penularan HIV: Saya Berani, Saya Sehat! Published online 2018.

https://www.kemkes.go.id/article/view/18 120300001/hari-aids-sedunia-momenstop-penularan-hiv-saya-berani-sayasehat-.html

4. Putri. Data Juni 2019, Penderita HIV/AIDS di Indonesia Sebanyak 349.883. Published online 2019. http://infopublik.id/kategori/sosial-

budaya/390058/data-juni-2019-penderitahiv-aids-di-indonesia-sebanyak-349-

883\#: :text=Data Juni 2019\%2C Penderita HIV\%2FAIDS di Indonesia Sebanyak 349.883,-Selasa\%2C 3 Desember\&text=Jakarta\%2C InfoPublik Peringatan $\mathrm{H}$

5. UNAIDS. Unaids data 2017. Published online 2017.

6. Aggarwal S, Yu L, Hasjim B, et al. Stigma and negative self-perceptions of young people living with human immunodeficiency virus in Bandung, Indonesia: A case series. Int Health. 2018;10(5):401-403.

doi:10.1093/inthealth/ihy031

7. Subu MA. "Between us and them" understanding stigma and stigmatization among people with human immunodeficiency virus (HIV) / acquired immune deficiency syndrome (AIDS) in Sumatera Island, Indonesia. ASEAN $J$ Psychiatry. 2017;18(1):0-0.

8. Kemenkes RI. Peraturan Menteri Kesehatan RI No. 87 Tahun 2014 Tentang Pedoman Pengobatan Antiretroviral.; 2014.

http://preventcrypto.org/wpcontent/uploa ds/2015/10/IndonesiaAdultARTguideline 
s20141432907\%0A982.pdf

9. WHO. Kajian Nasional Respon HIV Di

Bidang Kesehatan Republik Indonesia.;

2017.

http://www.searo.who.int/indonesia/publi

cations/hiv_country_revie\% $\% \mathrm{Aw}_{\text {_ }}$

indonesia_bahasa.pdf

10. Suparyanto. Pasangan Usia Subur. Published online 2012.

http://www.handilbakti.com/2013/06/\%0

Apasangan-usia-subur.html.

11. Harianti R, Nurbaiti. KARAKTERISTIK

, PENGETAHUAN DAN SIKAP PASANGAN USIA SUBUR TENTANG KABUPATEN INDRAGIRI HULU The Characteristics , Knowladge , and Attitudes Merried Couples of Reproductive Age about Sexually Transmitted Diseases in Clinic "Y" Indragiri Hulu STIKes Al-Ins. Kesehat Reproduksi. 2017;7(3):199-209.

12. Rahmayani V, Hanif AM, Sastri S. Hubungan Pengetahuan dan Sikap dengan Tindakan Pencegahan Penularan HIVAIDS pada Waria di Kota Padang Tahun 2013. J Kesehat Andalas. 2014;3(2):238243. doi:10.25077/jka.v3i2.99

13. Eviyanti. Laki-Laki Suka Laki Dominasi Kasus HIV/Aids 2020 Di Cilacap, Bahayanya Seks Sesama Jenis.(2020). https://portalpurwokerto.pikiranrakyat.com/banyumas-raya/pr115931549/laki-laki-suka-laki-dominasikasus-hivaids-2020-di-cilacapbahayanya-seks-sesamajenis\#: :text=PORTAL PURWOKERTO -Jumlah penderita HIV,2020 totalnya mencapai 1.755 ODHA. 